\title{
The effects of PC-Spes on chemosensitive and chemoresistant head and neck cancer cells and primary mucosal keratinocytes
}

\author{
MARIANNE SCHMIDT, CHRISTINE POLEDNIK, PETRA GRUENSFELDER, \\ JEANETTE ROLLER and RUDOLF HAGEN
}

Department of Otorhinolaryngology, University of Würzburg, Josef-Schneider-Strasse 11, D-97080 Würzburg, Germany

Received October 20, 2008; Accepted January 5, 2009

DOI: $10.3892 /$ or_00000354

\begin{abstract}
PC-Spes is a preparation of eight Chinese herbs, which exhibits antiproliferative and antitumour activity in diverse cancer types in vivo and in vitro. We exposed the head and neck squamous carcinoma cell lines (HNSCC) FADU, HLaC79 and HLaC79-clone1, which is a paclitaxelresistant descendant of HLaC79, as well as primary cultured mucosal keratinocytes to increasing concentrations of paclitaxel and/or PC-Spes. Growth inhibition was measured using the MTT assay. While FADU and HLaC79 were growth inhibited by paclitaxel, HLaC79-clone1 cells proved to be resistant against paclitaxel up to doses of $100 \mathrm{nM}$, whereas all three cell lines were growth inhibited by PC-Spes. Interestingly primary keratinocytes were less sensitive to PC-Spes, they even showed better survivel at low PC-Spes doses. Furthermore, we analyzed cell cycle distribution, apoptosis and tubulin expression level and polymerization status in the HNSCC cell lines. PC-Spes caused a slight decrease of cells in S/G2 phase in HLaC79-clone1. In FADU and HLaC79 cells the cell cycle was shifted towards S/G2 phase as expected. Apoptosis was initiated in all three cell lines by PC-Spes, in mucosal keratinocytes, however, it was triggered less distinctively. In summary, PC-Spes revealed distinct growth inhibition in a paclitaxel-resistant cell line, whereas primary mucosal keratinocytes were less sensitive. PC-Spes might therefore provide a therapeutical approach in chemoresistant head and neck cancer.
\end{abstract}

\section{Introduction}

PC-Spes is a herbal blend containing partial extracts of the Chinese herbs, Dendrantherma morifolium, Ganoderma lucidium, Glycyrrhiza glabra, Isatis indigotica, Panax pseudoginseng, Robdosia rubescens, Scutellaria baicalensis and Serenoa repens. Herbal therapy in the treatment of malignant

Correspondence to: Dr Marianne Schmidt, Department of Otorhinolaryngology, University of Würzburg, Josef-SchneiderStrasse 11, D-97080 Würzburg, Germany

E-mail: marianne.schmidt@klinik.uni-wuerzburg.de

Key words: PC-Spes, head and neck carcinoma, paclitaxel, apoptosis, herbal drug diseases has increased during recent years, especially in the USA (1) and there are now a variety of clinical studies on the efficiency of PC-Spes chemotherapy in prostate cancer (2-4).

The antineoplastic drug paclitaxel is a naturally occurring diterpenoid, isolated from the pacific yew (taxus brevifolia). Paclitaxel accelerates the polymerization of tubulin monomers, thus stabilizing microtubules and inhibiting the normal dynamic microtubule network reorganization. In practice paclitaxel is used as a chemotherapeutic agent for the treatment of head and neck cancer patients either alone or in combination with other cytotoxic agents or radiotherapy. Single-agent paclitaxel was tested in several studies and proved to be active in patients with squamous cell carcinoma of the head and neck. Response rates varied from 20 to $40 \%$ (reviewed in ref. 5).

We established a paclitaxel resistant clonal subline of the larynx carcinoma cell line $\mathrm{HLaC79}$ (6) and tested the effect of PC-Spes both on drug sensitive and resistant cells, and on the hypopharyngeal cancer cell line FADU. Furthermore, we tested PC-Spes for the first time on primary non-cancerous cells. We performed growth inhibition/cytotoxicity assays, analyzed tubulin expression levels and polymerization status. Moreover, we investigated cell cycle distribution and apoptotic behaviour of the cell lines, treated with taxol or PC-Spes, respectively. Results were compared with previous studies and critically discussed with respect to a hypothetical practical application of PC-Spes in head and neck cancer.

\section{Materials and methods}

Cell lines and cell culture. The head and neck squamous carcinoma cell line HLaC79 has been established from a lymph node metastasis of a laryngeal squamous cell carcinoma (7). The cell line was grown with RPMI-1640 medium (Seromed, Munich, Germany), supplemented with $10 \%$ fetal calf serum (FCS). HLaC79 cells were treated with $10 \mathrm{nM}$ paclitaxel. A resistant clone was isolated using the 'ring technique', i.e. a metal ring was placed over the clonal population and isolated by trypsination inside the ring (8). The permanent HLaC79 clonal cell line HLaC79-clone1 was cultured in RPMI-1640 medium, supplemented with $10 \%$ FCS and $10 \mathrm{nM}$ paclitaxel. FADU cells were grown in RPMI-1640 medium. Mucosal keratinocytes were prepared from mucosal samples of the upper aerodigestive tract. In brief, tissue samples were incubated for $12 \mathrm{~h}$ in dispase (Boehringer Mannheim, Germany; $25 \mathrm{U} / \mathrm{ml}$ ). Subsequently, epithelial sheets were 
dissected manually, and dissociated with trypsin (Gibco, Eggenstein, Germany). Dissociation was stopped with soybean trypsin inhibitor (Gibco; $10 \mathrm{mg} / \mathrm{ml})$, and cells were cultivated in keratinocyte-SFM (serum-free medium for keratinocytes; Gibco) at $37^{\circ} \mathrm{C}$ and $5 \% \mathrm{CO}_{2}$.

PC-Spes. PC-Spes was purchased as 'PC-Spes, new formula' (Medpro Holland B.V., Scherpenzeel, The Netherlands) and is composed according to the package leaflet as follows: 1 capsule PC-SPES (320 mg) contains: Ganoderma lucidum (Reishi), $99.2 \mathrm{mg}$; Scutelleria baicalensis (Scullcap), $51.2 \mathrm{mg}$; Rabdosia rubescens, $35.2 \mathrm{mg}$; Isatis indogotica, $32.0 \mathrm{mg}$; Dendranthema morifolium, $25.6 \mathrm{mg}$; Panax ginseng, $25.6 \mathrm{mg}$; Serenoa repens (Saw palmetto), $19.2 \mathrm{mg}$; Glycyrrhiza glabra, $3.2 \mathrm{mg}$.

The substance was extracted with ethanol. Ten capsules ( $3.2 \mathrm{~g})$ were dissolved in $10 \mathrm{ml}$ ethanol and incubated for $1 \mathrm{~h}$ at $37^{\circ} \mathrm{C}$. Insoluble particles were removed by low-speed centrifugation and filtration through a $22-\mu \mathrm{m}$ filter. Aliquots were stored at $-20^{\circ} \mathrm{C}$. To avoid inter-batch variability for all experiments PC-Spes of one single batch was used.

Cell viability and proliferation assay. Cells were seeded at 5000 cells/well in 96-well plates. They were treated with increasing concentrations of paclitaxel (10-200 nM) or PCSpes $(0.5-10 \mu \mathrm{l} / \mathrm{ml})$ in RPMI medium for $24 \mathrm{~h}$. Controls were kept in medium without drugs. PC-Spes controls were kept in $10 \mu \mathrm{l} / \mathrm{ml}$ ethanol. Cell proliferation was measured by replacing the culture medium with medium containing $1 \mathrm{mg} / \mathrm{ml}$ MTT (3-(4,5-dimethylthiazole-2-yl)-2,5-diphenyl tetrazolium bromide). After $4 \mathrm{~h}$ of incubation, MTT-staining solution was replaced by isopropanol and cells were incubated at $37^{\circ} \mathrm{C}$ overnight. The colour conversion of MTT to a blue formazan dye was measured with an ELISA (enzyme linked immunosorbent assay) reader at a wavelength of $570 \mathrm{~nm}$. The amount of formazan dye is in direct proportion to the number of metabolically active cells in the culture.

Cell cycle distribution. Cells were treated with $10 \mathrm{nM}$ paclitaxel or $10 \mu \mathrm{l} / \mathrm{ml} \mathrm{PC}-$ Spes for $24 \mathrm{~h}$. Controls received medium with or without ethanol. After this incubation the medium was changed and cells were grown for an additional $24 \mathrm{~h}$. DNA content was then measured by staining with $40 \mu \mathrm{g} /$ $\mathrm{ml}$ propidium iodide (Sigma Aldrich, Deisenhofen, Germany) and $100 \mu \mathrm{g} / \mathrm{ml}$ RNAse (Qiagen, Hilden, Germany) in PBS for $30 \mathrm{~min}$ at $37^{\circ} \mathrm{C}$. FACS (fluorescence activated cell sorting) analysis was performed with a FACSCalibur ${ }^{\circledR}$ flow cytometer using CellQuest ${ }^{\circledR}$ software (Becton Dickinson, Heidelberg, Germany).

Apoptosis - FACS analysis with Annexin V antibodies. FACS analysis was performed using the Annexin V-APC kit of BD Pharmingen (BD Biosciences, Heidelberg, Germany) according to the kit manual. In brief, cells treated with $10 \mathrm{nM}$ paclitaxel or $10 \mu \mathrm{g} / \mathrm{ml} \mathrm{PC}$-Spes for $8 \mathrm{~h}$, were harvested and washed twice with cold PBS. Cells were then resuspended in $1 \mathrm{X}$ binding buffer (0.1 M Hepes, $\mathrm{pH} 7.4,1.4 \mathrm{M} \mathrm{NaCl}, 25 \mathrm{mM}$ $\mathrm{CaCl}_{2}$ ) at a concentration of $1 \times 10^{6}$ cells $/ \mathrm{ml}$. To $100 \mu \mathrm{l}$ of this cell suspension $5 \mu \mathrm{l}$ Annexin V-APC and $5 \mu 1$ 7-AAD (7amino-actinomycin $\mathrm{D}$, included in the kit) were added, the

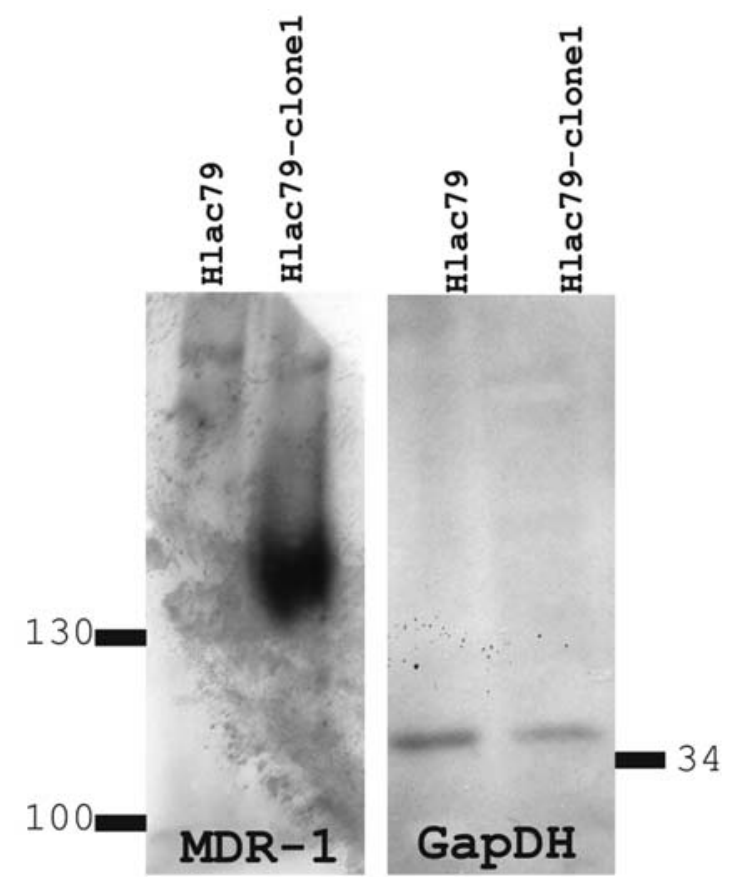

Figure 1. Western blot analysis of MDR-1 (multi-drug resistance gene 1) expression in HLaC79 and the descendant subline HLaC79-clone1. The right blot shows a loading control, performed with a glyceraldehyde-3phosphate dehydrogenase (GAPDH) monoclonal antibody. Molecular weight standards are specified in $\mathrm{kDa}$ (kilodalton).

cells were vortexed and incubated for 15 min in the dark. Four hundred $\mu \mathrm{l}$ of $1 \mathrm{X}$ binding buffer was added. Within $1 \mathrm{~h}$ FACS analysis was performed at an excitation wavelength of $650 \mathrm{~nm}$.

Tubulin immunohistochemistry. For tubulin staining cells were washed several times with ice-cold PBS, fixed with microtubule fixative $(0.1 \mathrm{M}$ PIPES, $1 \mathrm{mM}$ EGTA, $1 \mathrm{mM}$ $\mathrm{MgCl}_{2}, 1 \%$ Triton X-100, $\%$ paraformaldehyde, $\mathrm{pH}$ 6.8) for $20 \mathrm{~min}$ at $37^{\circ} \mathrm{C}$. The fixed cells were washed twice with PBS for $10 \mathrm{~min}$, extracted with methanol for $5 \mathrm{~min}$ at $-20^{\circ} \mathrm{C}$ and again washed with PBS for $10 \mathrm{~min}$. The cells were blocked with $5 \%$ goat serum for $30 \mathrm{~min}$ and subsequently incubated overnight at $4{ }^{\circ} \mathrm{C}$ with the primary polyclonal rabbit anti- $\alpha$ tubulin antiserum (Santa Cruz Biotechnology, Heidelberg, Germany) in PBS containing $0.1 \%$ bovine serum albumin. After extensive washing with cold PBS cells were incubated with the secondary Cy2(cyanine)-conjugated anti-rabbit antibody (Sigma-Aldrich, Munich, Germany) for $1 \mathrm{~h}$ at room temperature. After washing with PBS slides with cells were mounted with antifade $(25 \mathrm{mg} / \mathrm{ml} \mathrm{1,4-diazabicyclo[2.2.2]}$ octane in $30 \%$ glycerol) and analyzed by fluorescence microscopy.

Western blot analysis. For Western blot analysis, cells were harvested by trypsination, and dissolved in RIPA [PBS, containing 1\% NP40 (nonidet P40), $0.5 \%$ sodium deoxycholate, $0.1 \%$ SDS (sodium dodecyl sulfate)], supplemented with $10 \mu \mathrm{g} / \mathrm{ml}$ phenylmethanesulfonyl fluoride (PMSF). Protein content was determined according to the method of Lowry (9). Equal amounts of total protein lysates were loaded on 

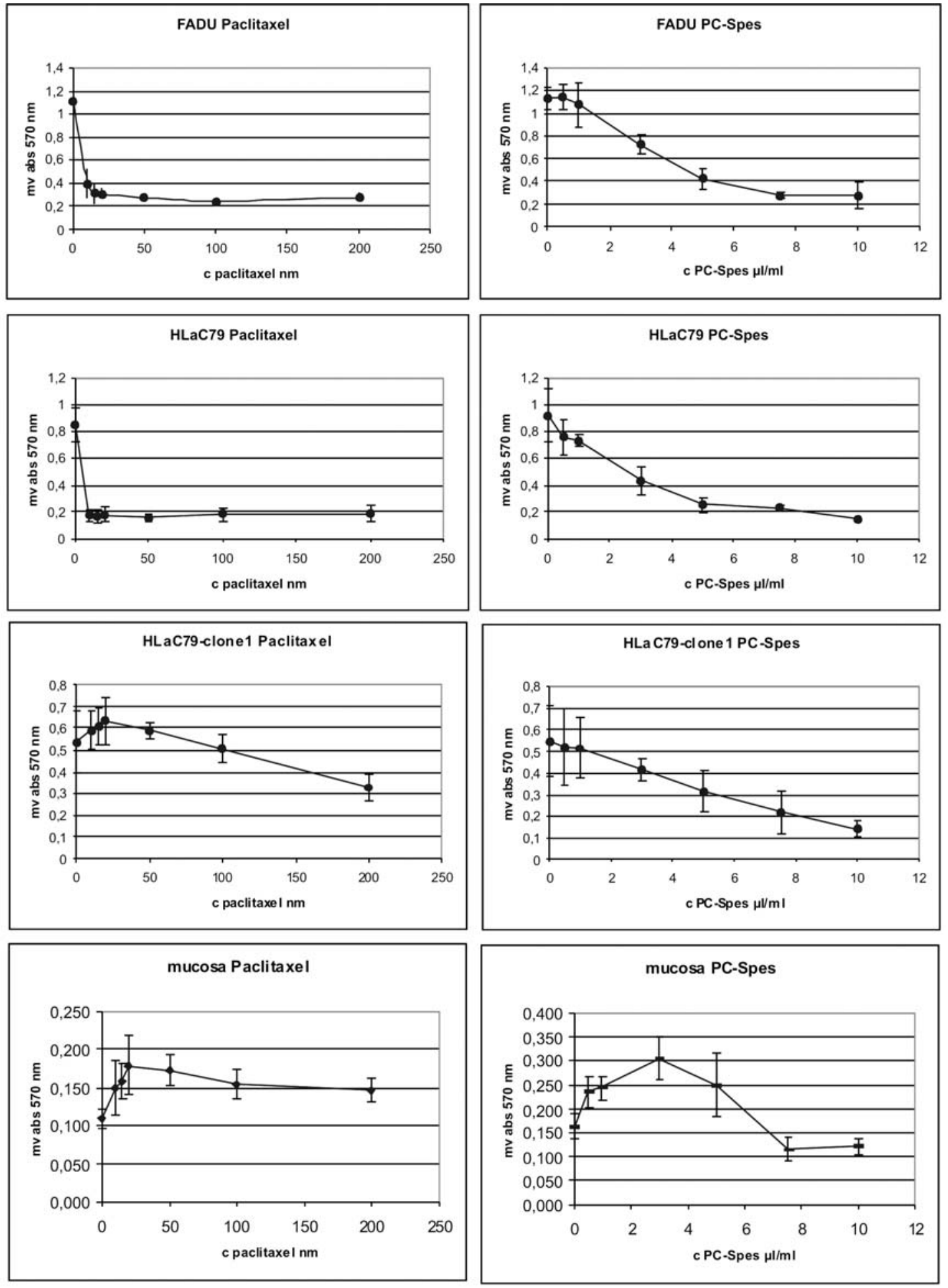

Figure 2. Absorbance curves (y-axis) of the MTT assay performed on HLaC79, HLaC79-clone1, FADU and primary mucosal cells (MC) with increasing concentrations of paclitaxel (left panels) or PC-Spes (right panels) at $570 \mathrm{~nm}$. The absorbance correlates directly with the number of living cells. Mv, mean value of 12 tests.

$10 \%$ SDS-polyacrylamide gels and run at a constant current of $20 \mathrm{~mA}$ (miliampere). Gels were blotted onto nitrocellulose membranes according to the semidry method of KyhseAndersen (10). Blots were blocked overnight with TBST (10 mM Tris, $150 \mathrm{mM} \mathrm{NaCl}, 0.05 \%$ Tween-20, $\mathrm{pH} 8.0$ ), containing $5 \%$ non-fat dry milk. For detection of $\alpha / \beta$ tubulin and MDR-1/P-gp monoclonal antibodies were used (Sigma Deisenhofen, Germany). As secondary antibody we used a peroxidase-conjugated goat anti-mouse IgG serum (Sigma). For loading controls a monoclonal glyceraldehyde-3-phosphate dehydrogenase antibody (Chemicon, Schwalbach, Germany) was used. Detection of bound antibody conjugates was performed with the enhanced chemiluminescence system (ECL, Amersham Biosciences, Freiburg, Germany), according to the manufacturer's protocol. 
Co
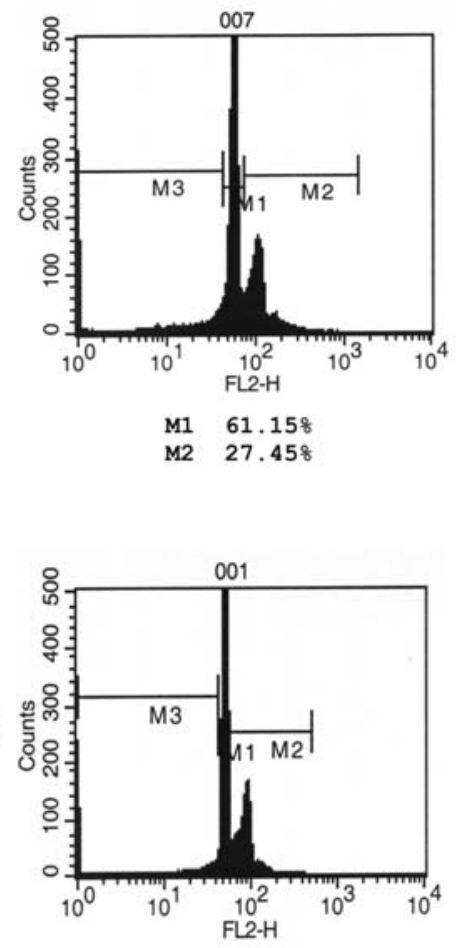

M1 72.118

M2 $22.37 \%$

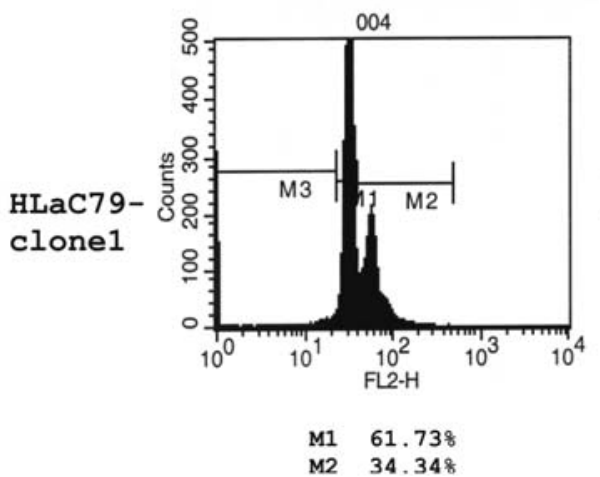

PC-Spes
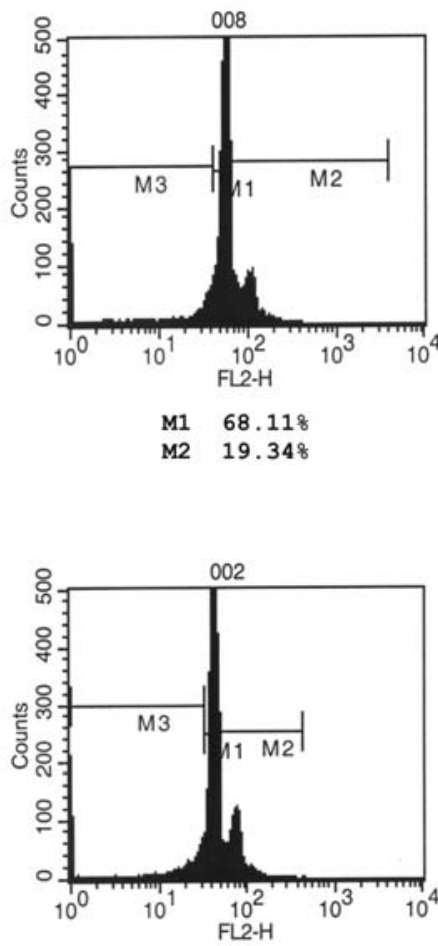

M1 68.68 ?

M2 $19.85 \%$

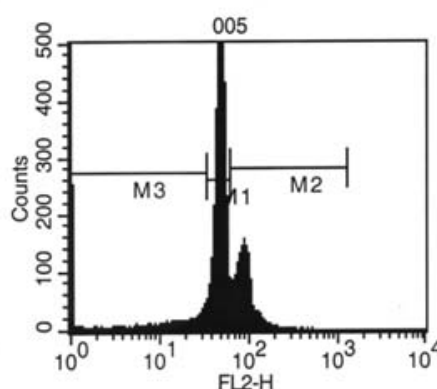

$\begin{array}{ll}\text { M1 } & 59.93 \% \\ \text { M2 } & 25.81 \%\end{array}$
Paclitaxel
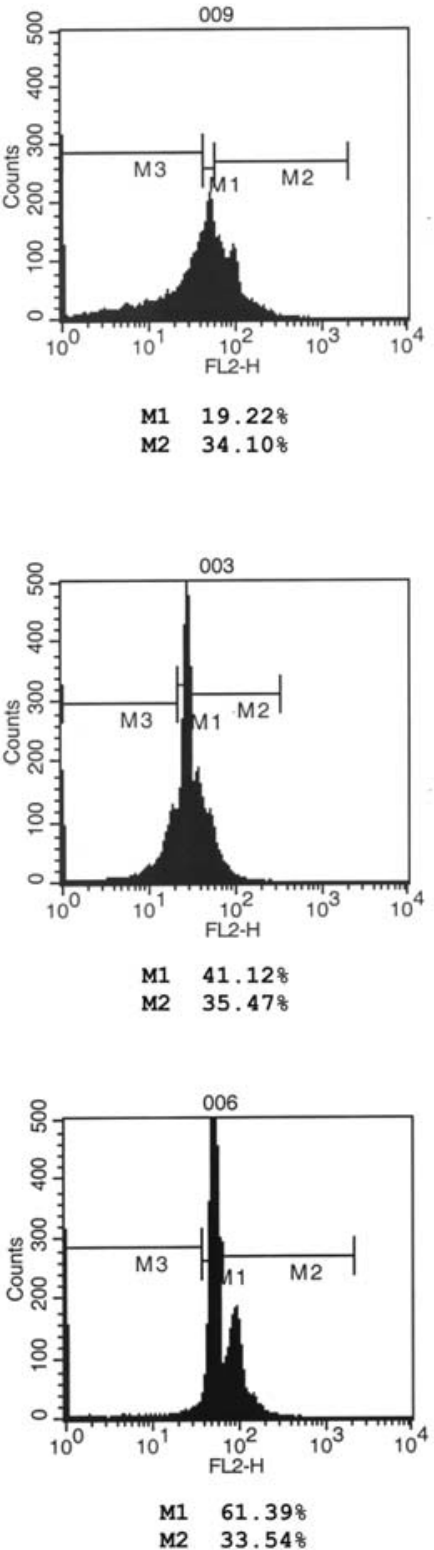

Figure 3. Cell cycle analysis in HLaC79, HLaC79-clone1 and FADU cells, treated with $10 \mathrm{nM}$ paclitaxel or $10 \mu 1 / \mathrm{ml}$ PC-Spes for 24 h. M1, G0/G1 fraction; M2, S/G2 fraction. Untreated control cells are marked as Co.

Densitometric analysis was performed by scanning the $\mathrm{X}$-ray film and evaluating the bands with the Image software (NIH, USA).

\section{Results}

Establishment of the taxol resistant cell line HLaC79-clone1. The larynx carcinoma cell line HLaC79 was treated with $10 \mathrm{nM}$ paclitaxel diluted in complete culture medium. In one of the culture flasks treated with taxol a few cells survived and proliferated. The surviving cells developed in a subline, optically not distinguishable from the parental cell line. The growing cell clone was isolated and kept with $10 \mathrm{nM}$ paclitaxel as a permanent clonal cell line. Western blot analysis with an antibody against P-glycoprotein showed distinct over- expression of the drug efflux pump in HLaC79-clone1 cells (Fig. 1).

Cell proliferation and viability assay. The three cell lines and primary mucosal keratinocytes were treated with increasing concentrations of paclitaxel or PC-Spes. After a 48-h incubation cell viability and cytotoxicity of the used drugs were measured with the MTT assay. Paclitaxel suppressed the growth of HLaC79 and FADU cells significantly at the low dose of $10 \mathrm{nM}$ (Fig. 2). HLaC79-clone1 in contrast showed nearly no growth inhibition up to concentrations of $100 \mathrm{nM}$ paclitaxel (Fig. 2). Mucosal keratinocytes also showed reduced growth inhibition after paclitaxel treatment. This is probably caused by low mitotic activity in these primary cultures. PC-Spes inhibited the growth of all three cell lines in a dose-dependent 


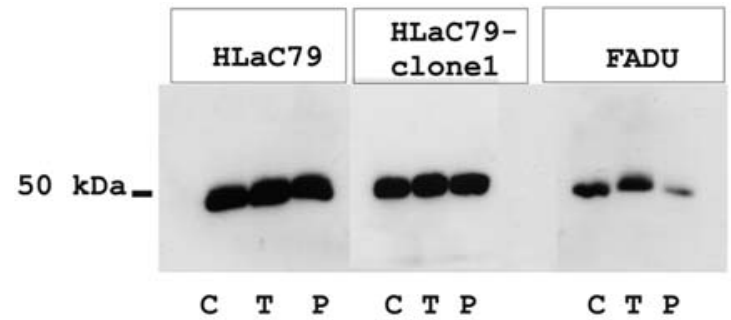

alphatubulin
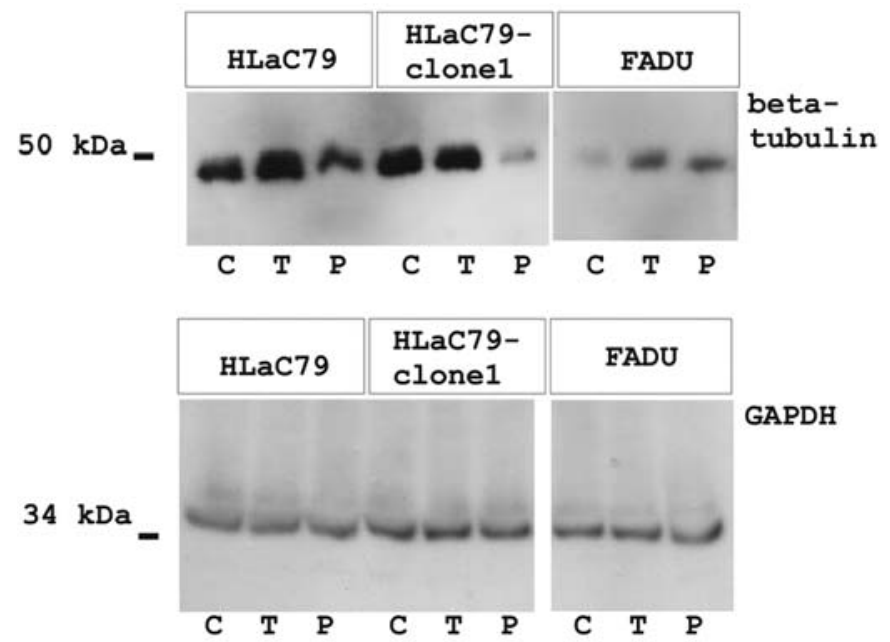

GAPDH

Figure 4. Western blot of the cell lines FaDU, HLaC79 and HLaC79-clone1 Cells were treated with $10 \mathrm{nM}$ paclitaxel or $10 \mu \mathrm{l} / \mathrm{ml}$ for $24 \mathrm{~h}$ PC-Spes and subsequently equal amounts of total protein were loaded on PA-gels. Blots were incubated with antibodies against $\alpha$-/ $\beta$-tubulin or the loading control antibody against glyceraldehyde-3-phosphate dehydrogenase (GAPDH), respectively. C, untreated control; P, PC-Spes; T, paclitaxel (taxol). Molecular weight is indicated in $\mathrm{kDa}$ (kilodalton).

manner (Fig. 2). Mucosal keratinocytes conspicuously seemed to be resistant to low PC-Spes doses, they even showed better survival at doses up to $6 \mu \mathrm{l} / \mathrm{ml} \mathrm{PC}$-Spes.

Apoptosis. FACS analysis with the Annexin V-APC kit revealed significantly increased apoptotic cell fractions after $8 \mathrm{~h}$ of incubation with PC-Spes in all three cell lines, including the paclitaxel-resistant clone1 of the parental cell line HLaC79 (Fig. 6: HLaC79-clone1 $35.6 \%$ apoptotic fraction; HLaC79 $40.5 \%$, FADU $23.5 \%$ ), whereas paclitaxel did not trigger apoptosis in HLaC79-clone 1 as expected. Apoptosis was initiated in HLaC79 and FADU cells by paclitaxel (Fig. 6: HLaC79 14.4\% apoptotic cells; FADU 30.7\% apoptotic cells). HLaC79-clone1 cells showed even less apoptotic cells than the untreated control cells after paclitaxel treatment, which indicates a partial dependency on the drug (Fig. 6). In mucosal keratinocytes neither PC-Spes nor paclitaxel triggered apoptosis to a large extent after $8 \mathrm{~h}$ (Fig. 6: 5.0\% apoptotic cells triggered by paclitaxel and $5.4 \%$ apoptotic cells after treatment with $\mathrm{PC}$-Spes), which indicates, that both drugs might reach stronger effects in fast growing tumour cell populations.

Cell cycle analysis. In order to determine if there was any alteration in the cell cycle distribution caused by the drugs, cells were cultured with or without paclitaxel/PC-Spes for $24 \mathrm{~h}$, incubated for further $24 \mathrm{~h}$ without toxic agents and
Table I. Expression levels of $\alpha$ - or $\beta$-tubulin caused by paclitaxel or PC-Spes in percent of the untreated control $($ Control $=100 \%)$.

\begin{tabular}{lccr}
\hline & \multicolumn{3}{c}{$\alpha$-Tubulin } \\
\cline { 2 - 4 } & HLaC79 & HLaC79-clone1 & FADU \\
\hline Paclitaxel & 112 & 108 & 104 \\
PC-Spes & 90 & 107 & 25 \\
\hline & \multicolumn{3}{c}{ B-Tubulin } \\
\cline { 2 - 4 } & HLaC79 & HLaC79-clone1 & FADU \\
\hline Paclitaxel & 151 & 85 & 347 \\
PC-Spes & 109 & 17 & 318 \\
\hline
\end{tabular}

${ }^{a}$ Values were determined by scanning the blots and densitometric analysis with the ImageJ software (NIH, USA).

subsequently permeabilized and stained with propidium iodide. As shown in Fig. 3, both the parental cell line HLaC79 and the taxol-resitant clone display similar cell cycle profiles in the absence of paclitaxel (- tax). G0/G1 (diploid) is indicated by M1, S and G2/M by M2 in \% of cells measured (Fig. 3).

In FADU and $\mathrm{HLaC79}$ cells the cell cycle was shifted towards S/G2 phase (M2 fraction) by application of paclitaxel as expected. In contrast the cell cycle of HLaC79-clone1 was not significantly affected by paclitaxel application. Cells of the paclitaxel resistant clone of HLaC79 showed an unaltered phase distribution (Fig. 3), when compared to untreated control cells. All three cell lines showed a slight percentual decrease of the S/G2 fraction caused by PC-Spes (Fig. 3). This is in contrast to the observations in colon cancer cell lines (11), where a drastic accumulation of cells in the S/G2 phase was described as well as with the results of Schwarz et al (12) who tested diverse pancreatic cell lines. In these cell lines a $\mathrm{G} 2 / \mathrm{S}$ phase accumulation $(11,12)$ was observed. This result suggests that the effect of PC-Spes on cell cycle shift might be cell type-dependent.

Tubulin expression. We analyzed the expression levels of the tubulin subtypes $\alpha$ and $\beta$ by antibody detection on Western blots. Results are displayed in Fig. 4. Western blot analysis revealed that expression levels of both $\alpha$ - and $\beta$-tubulin changed cell type-dependently after chemotherapeutic treatment either with paclitaxel or PC-Spes (Fig. 4). Densitometric analysis results are summarized in Table I.

Most drastic is the down-regulation of $\alpha$-tubulin by PCSpes and up-regulation of $\beta$-tubulin in FADU cells by PCSpes and paclitaxel as well as the down-regulation of $\beta$-tubulin in HLaC79-clone1 caused by PC-Spes. Obviously expression of the tubulin subunits can be disturbed by drugs such as paclitaxel or PC-Spes, but this seems to happen in a cell typedependent manner.

Tubulin polymerization status. We further visualized cellular microtubule networks by indirect immunofluorescence staining 


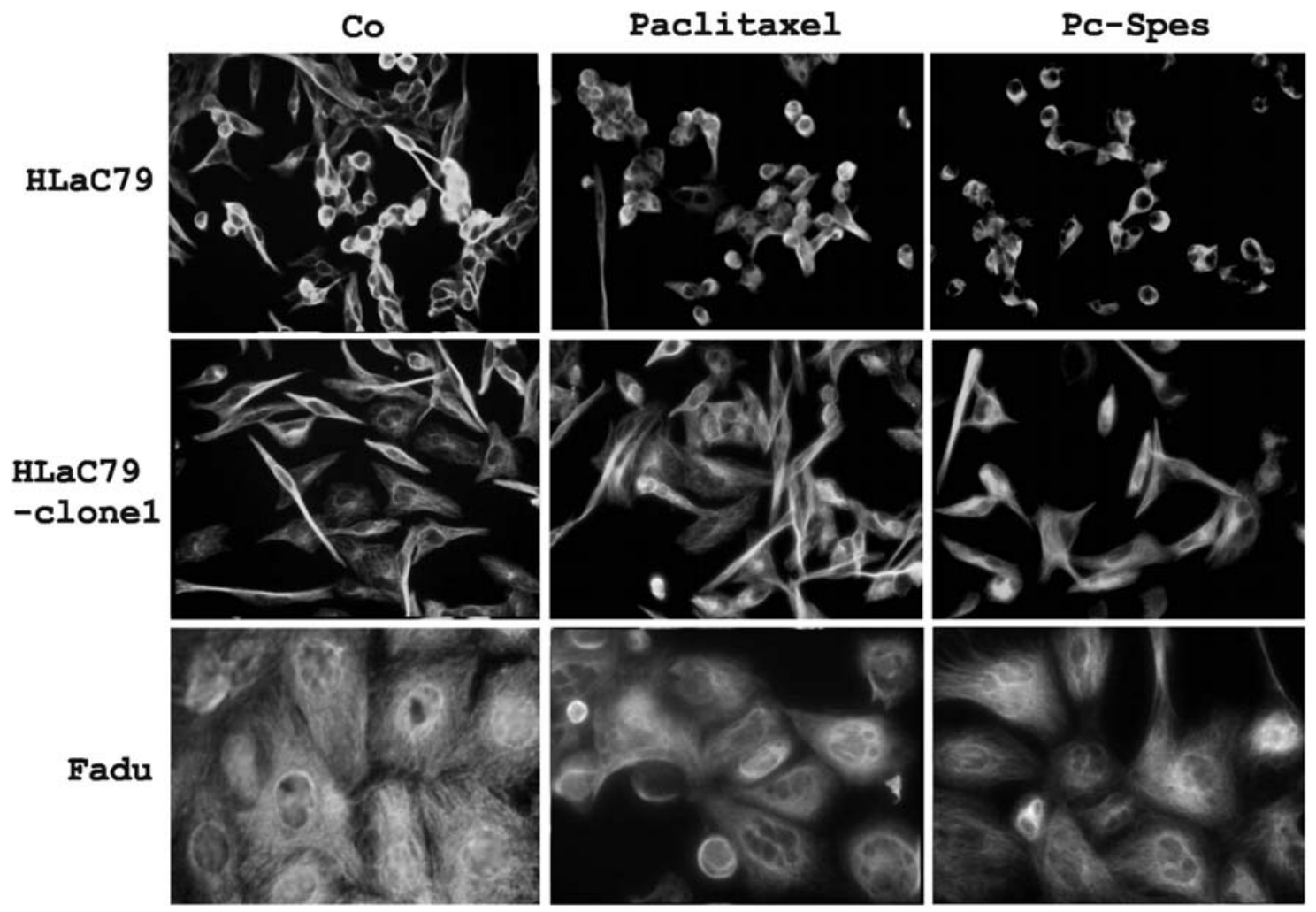

Figure 5. Immunofluorescence staining of cultured cells with an antibody against $\alpha$-tubulin, treated with paclitaxel $(10 \mathrm{nM})$ or PC-Spes (10 $\mu 1 / \mathrm{ml})$ for $24 \mathrm{~h}$, respectively. Co, untreated control cells.

with an anti- $\alpha$-tubulin antibody in order to determine whether the assembly of tubulin into microtubules was changed by application of the drugs paclitaxel or PC-Spes, respectively. Drug-treated cells and untreated control cells showed staining patterns as demonstated in Fig. 5

Bonham et al (13) described a disruption of microtubule networks caused by PC-Spes in the LNCaP prostate carcinoma cell line after $8 \mathrm{~h}$ of treatment, and a complete dispersion after $24 \mathrm{~h}$, visible as a punctuate tubulin staining pattern. In contrast, in our cell lines a dispersion of tubulin staining could not be observed after a 24-h incubation with the toxic agents. In untreated cell lines, microtubules formed a fine extensive network throughout the cytoplasm, generally aligned with the cell axis. This orientation was maintained with the treatment of microtubule stabilizing paclitaxel as expected. However, staining of PC-Spes-treated cells showed a similar distribution of microtubule staining after $24 \mathrm{~h}$. The microtubule cytoskeleton appeared somewhat collapsed after cytotoxic treatment in HLaC79 and FADU cells as well as in PC-Spes treated HLaC79-clone 1 cells, which can be explained by rounding and partial detachment of the cells from the surface of the culture dish.

\section{Discussion}

In advanced laryngeal and hypopharyngeal cancer the functional and cosmetic deformations produced by surgery can be very disabling for the patients. The chemotherapeutic agent paclitaxel is meanwhile commonly used for chemotherapy of inoperable or advance head and neck cancer in order to preserve laryngeal and/or pharyngeal structures.
Although paclitaxel generally seems to be a powerful agent, it failed to reach a local-regional tumour control in $12 \%$ of patients according to a previously published study (5). Chemotherapeutic failure may be related either to inherited resistance against the drug or/and the acquirement of resistance during the therapy. Drug resistance is mostly a multi-factorial procedure, in the case of paclitaxel several mechanisms have been described. One mechanism is the overexpression of P-glycoprotein (coded by the multi-drug resistance gene 1 , MDR-1). We were able to verify MDR-1 overexpression in HLaC79-clone1 cells.

During the last decades alternative medicines have gained significant potential as replacements or support to conventional cancer therapy. Traditional Chinese herbs often have been used both for disease prevention and treatment. A better understanding of the molecular mechanisms of purified plant components is necessary for the design of new cancer therapy strategies.

The herbal preparation PC-Spes has been an alternative form of therapy for prostate cancer patients for years. PC-Spes was available as a dietary supplement and it contained extracts of eight different herbs, Scutellaria baicalensis, Glycyrrhiza glabra, Ganoderma lucidum, Isatis indigotica, Panax pseudoginseng, Dendranthema morifolium tzavel, Rabdosia rubescens and Serenoa repens. Herbs in PC-SPES have been used in traditional Chinese medicine for many health problems, including prostate problems, for hundreds of years. Certain batches of PC-SPES were found to contain prescription medicines such as warfarin or indomethacin. It was taken off the market in 2002. Since 2005 a herbal preparation is available on the European market, called 'PC-Spes, new formula', as has 
$\mathrm{HlaC} 79$
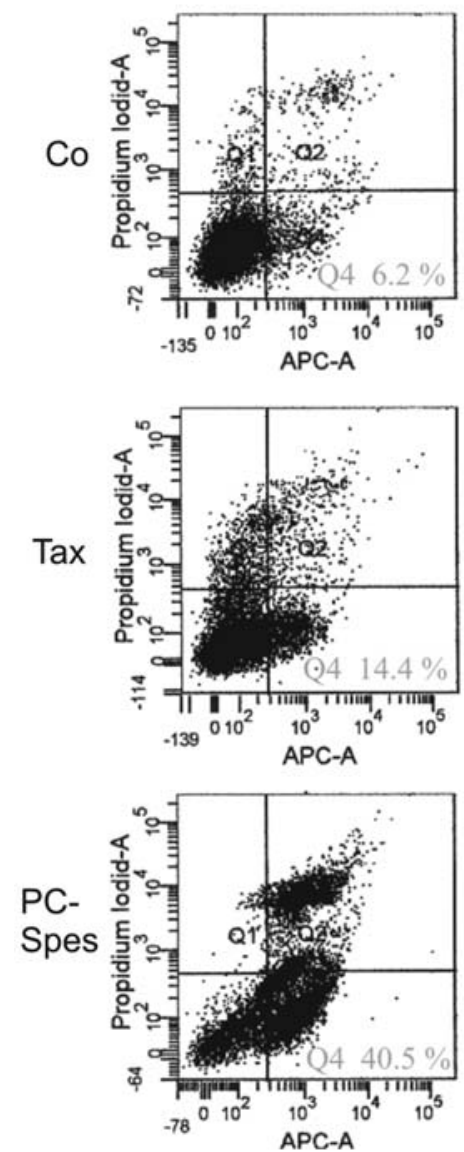

FADU
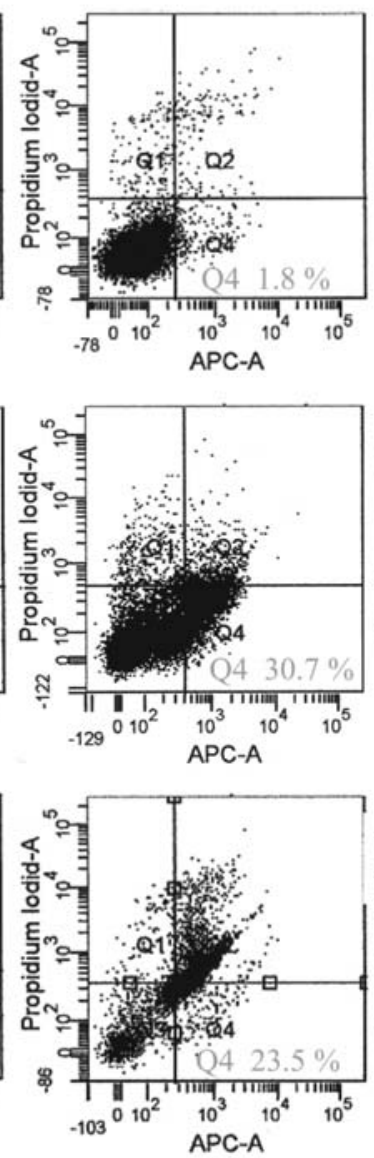

HlaC79-clone1
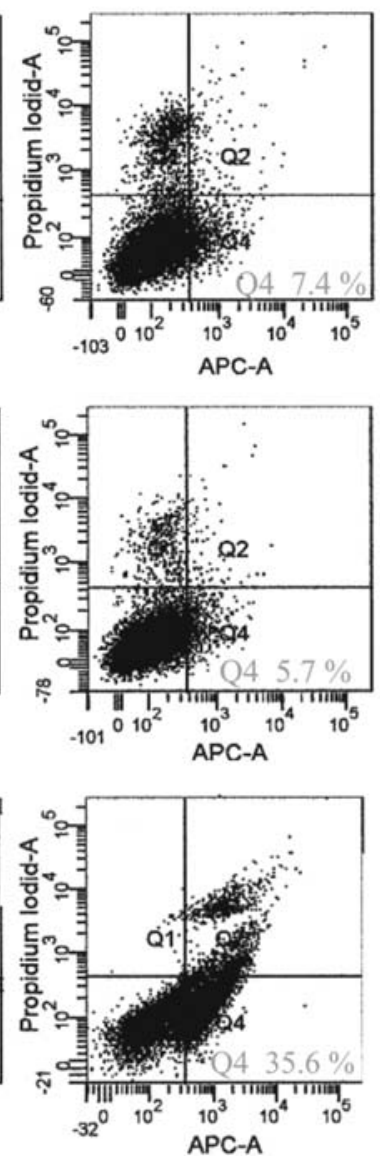

MC
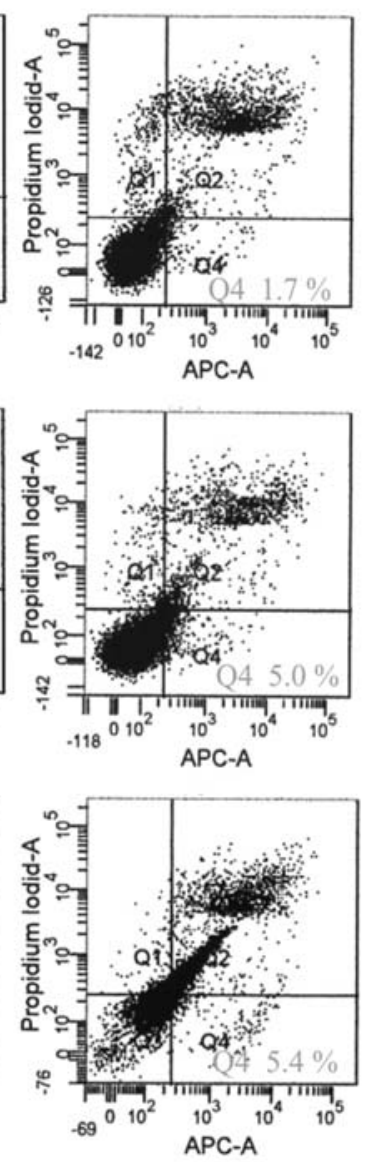

Figure 6. FACS analysis of cultured cells with the Annexin V-APC kit after $12 \mathrm{~h}$ incubation with paclitaxel (Tax; $10 \mathrm{nM}$ ) or PC-Spes (10 $\mu \mathrm{l} / \mathrm{ml})$. Cells $(10,000)$ were measured in each single experiment. Q4 shows the percentage of the apoptotic cell fraction. MC, mucosal cells; Co, untreated control.

been described previously (22). Like the original preparation it is sold as a nutritional supplement. According to the manufacturer's information this new formulation is produced in The Netherlands according to Dutch law and under control of the Dutch Ministry of Health. Recently PC-Spes2 was introduced to the UK, manufactured by Active Botanicals Ltd. with strict indepentantly-conducted quality control. Phase I trials in prostate cancer have already been performed (23). At present PC-Spes 2 is only available in limited amounts.

Several studies have reported the in vitro and in vivo efficacy of PC-Spes against prostate carcinoma (14), pancreatic cancer (12), colon cancer (11), breast cancer (15) and others. A phase II trial of 33 patients with androgendependent prostate cancer and 37 patients with androgenindependent prostate cancer proved the therapeutic efficacy of PC-Spes in a prospective fashion (4). Several compounds of PC-Spes have been shown to provide different anti-tumour properties independently. Thus baicalin, the main agent of Scutellaria baicalensis, has been demonstrated to inhibit proliferation in prostate and myeloblastic/promyelocytic leukaemia cell lines (15) or breast cancer cell lines (16), respectively. Rabdosia rubescens inhibits growth of breast cancer cells as well as angiogenesis (17), the active agents have been identified as ponicidin and oridonin (18).

The use of herbal medicines has been demonstrated to suppress even the growth of chemoresistant cells such as the cisplatin-resistant ovarian cancer cell line, A2780 (19). In our investigation, we show an apoptotic and anti-proliferative action of PC-Spes on a paclitaxel-resistant head and neck cancer cell line. We cloned a descendant taxol-resistant cell line of HLaC79, the original larynx carcinoma cell line and characterized it with respect to growth properties and gene expression, respectively (6). HLaC79-clone1 is paclitaxelresistant up to concentrations of $100 \mathrm{nM}$ paclitaxel. Probably resistance is induced at least partially by the overexpression of P-glycoprotein, which functions as an active, ATP-dependent efflux pump in the cell membrane. The growth inhibitory effect of PC-Spes on HLaC79-clone1 cells suggests that one or more compounds of the herbal mixture are not extruded by the efflux pump.

Mucosal keratinocytes are not growth inhibited by PCSpes at low doses. They even seem to show better survival with PC-Spes up to $6 \mu \mathrm{l} / \mathrm{ml}$ of the extract. This study is the first that has tested the effects of PC-Spes on growth of primary non-malignant cells and it gives evidence that PCSpes might be promising in targeting specifically tumour cells in cancer therapy.

In our study, Western blot analysis revealed that expression of the tubulin $\alpha$ - and $\beta$-subunits are quantitatively effected by application of PC-Spes (Fig. 4). Most drastic was the downregulation of $\alpha$-tubulin by $\mathrm{PC}$-Spes and up-regulation of ß-tubulin in FADU cells by PC-Spes and paclitaxel as well 
as the down-regulation of ß-tubulin in HLaC79-clone1 caused by PC-Spes. Bonham et al (20) described changes in $\alpha$-tubulin mRNA expression in diverse PC-Spes-treated cancer cell lines. B-tubulin expression was not examined by these authors. Furthermore, Bonham et al (20) examined tubulin expression at the RNA level; therefore, results cannot be compared directly. In any case, it seems that tubulin expression can be altered by PC-Spes, but there is no clear up- or downregulation, which occurs in all cell lines tested. Obviously tubulin disregulation is cell type-specific and/or is dependent on other factors such as chemoresistance and growth rates.

We were not able to influence the tubulin polymerization status either by paclitaxel or PC-Spes in the three cell lines tested. Bonham et al (13) described a punctuate pattern of tubulin antibody staining as soon as $12 \mathrm{~h}$ after PC-Spes application. We were not able to see such a punctuate pattern, even after $24 \mathrm{~h}$ PC-Spes treatment. It seems that the effects of PC-Spes on tubulin polymerization status are at least partially also cell type-/cell status-dependent.

It is widely known that paclitaxel, the poison of the pacific yew tree (taxus brevifolia), acts by inhibition of the microtubule disassembly, thus arresting cells in mitosis. Cell cycle analysis revealed a clear shift to $\mathrm{S} / \mathrm{G} 2$ phase in $\mathrm{HLaC} 79$ and FADU cells as expected. In HLaC79-clone1 cells, however, this shift did not take place. HLaC79-clone1 clonal cell line is resistant to paclitaxel and thus was not arrested in cell cycle. This might be explained by $\mathrm{P}$-glycoprotein overexpression in HLaC79-clone 1 cells. The gene locus MDR-1 codes for P-glycoprotein, an active, ATP-dependent transmembranous transporter, which is able to pump toxic agents out of cells. In contrast to paclitaxel PC-Spes caused in our cell lines a slight percentual decrease of cells in S/G2 phase, which differs from observations made previously in pancreatic or colon cancer cell lines, respectively. Schwarz et al (12) observed an S/G2 arrest caused by PC-Spes in several pancreatic cancer cell lines. Similar observations were made by Huerta et al (11) in colon cancer cell lines. The controversal results might be explained by a cell type-specific and/or cell status (high/low mitotic activity, kind of resistance) response to PC-Spes, particularly with regard to the still unknown cumulative effects of the single ingredients of PC-Spes.

In order to investigate the apoptotic effect of PC-Spes and paclitaxel we performed FACS (fluorescence activated cell sorting) analysis with an Annexin V antibody. Results clearly show a drastic percentage increase of apoptotic cells provoked by PC-Spes as well as by paclitaxel in FADU and HLaC79 cell lines. PC-Spes also triggered apoptosis in HLaC79clone1 whereas paclitaxel failed to induce apoptosis in the taxol-resistant HLaC79-clone1 cell line. Also in this case the missing toxic effect of paclitaxel in HLaC79-clone1 may be explained by the up-regulated P-glycoprotein expression in the resistant clone.

PC-Spes proved to be highly effective in apoptosis induction in chemoresistant HLaC79-clone1 cells. In mucosal keratinocytes apoptosis, however, was not strongly induced either by paclitaxel or PC-Spes. Thus, it seems possible that combinations of purified herbal compounds may be used in combination with conventional anticancer chemotherapy in order to achieve synergistic activities. It might be an approach for chemotherapeutical treatment of paclitaxel-resistant head and neck carcinomas, especially since PC-Spes showed less severe side effects in clinical studies than paclitaxel. Since PC-Spes acts like an oestrogen, the side effects are similar to other oestrogen-based hormone therapies, mainly composed of reduced libido, hot flashes, and gynaecomastia (21).

In summary, we demonstrated that PC-Spes can achieve growth inhibition in head and neck cancer cells, even if these cells are resistant to paclitaxel. The effect of PC-Spes seems to be not affected by increased expression of P-glycoprotein, which is a frequent mechanism in achieving resistance to cytotoxic agents. Furthermore, we show that primary nonmalignant mucosal cells are not strongly growth inhibited by PC-Spes. Future experiments include the combination of PCSpes with paclitaxel and other chemotherapeutical agents playing a role in head and neck carcinoma treatment. A further interesting question will be whether there exists a synergistic action of PC-Spes with radiation therapy.

\section{References}

1. DiPaola RS, Zang H, Lambert GH, Meeker R, Licitra E, Rafi MM, Zhu BT, Spaulding H, Goodin S, Toledano MB, Hait WN and Gallo MA: Clinical and biologic activity of an estrogenic herbal combination (PC-Spes) in prostate cancer. $\mathrm{N}$ Engl J Med 339: 785-791, 1998.

2. De la Taille A, Buttyan R, Hayek O, Bagiella E, Shabsigh A, Burchardt M, Burchardt T, Chopin DK and Katz AE: Herbal therapy PC-Spes: in vitro effects and evaluation of its efficacy in 69 patients with prostate cancer. J Urol 164: 1229-1234, 2000.

3. Moyad MA, Pienta KJ and Montie JE: Use of PC-Spes, a commercially available supplement for prostate cancer, in a patient with hormone-naive disease. Urology 54: 319-324, 1999.

4. Small EJ, Frohlich MW, Bok R, Shinohara K, Grossfeld G, Rozenblat Z, Kelly WK, Corry M and Reese DM: Prospective trial of the herbal supplement PC-Spes in patients with progressive prostate cancer. J Clin Oncol 18: 3595-3603, 2000.

5. Pfreundner L, Hoppe F, Willner J, Preisler V, Bratengeier K, Hagen R, Helms J and Flentje M: Induction chemotherapy with paclitaxel and cisplatin and CT-based 3D radiotherapy in patients with advanced laryngeal and hypopharyngeal carcinomas - a possibility for organ preservation. Radiother Oncol 68: 163-170, 2003.

6. Schmidt M, Schler G, Gruensfelder P and Hoppe F: Differential gene expression in a paclitaxel-resistant clone of a head and neck cancer cell line. Eur Arch Otorhinolaryngol 263: 127-134, 2006.

7. Zenner HP, Lehner W and Herrmann IF: Establishment of carcinoma cell lines from larynx and submandibular gland. Arch Otorhinolaryngol 225: 269-277, 1979.

8. McFarland D: Preparation of pure cell cultures by cloning. Methods Cell Sci 22: 63-66, 2000.

9. Lowry OH, Rosebrough NJ, Farr AL and Randall RJ: Protein measurement with the Folin phenol reagent. J Biol Chem 193: 265-275, 1951.

10. Kyhse-Andersen J: Electroblotting of multiple gels: a simple apparatus without tank for rapid transfer of proteins from polyacrylamide to nitrocellulose. J Biochem Biophys Methods 10: 203-210, 1984.

11. Huerta S, Arteaga JN, Irwin RW, Ikezoe T, Heber D and Koeffler HP: PC-Spes inhibits colon cancer growth in vitro and in vivo. Cancer Res 62: 5204-5209, 2002.

12. Schwarz RE, Donohue CA, Sadava D and Kane SE: Pancreatic cancer in vitro toxicity mediated by chinese herbs Spes and PCSpes: implications for monotherapy and combination treatment Cancer Lett 189: 59-68, 2003.

13. Bonham MJ, Galkin A, Montgomery B, Stahl WL, Agus D and Nelson PS: Effects of the herbal extract PC-Spes on microtubule dynamics and paclitaxel-mediated prostate tumor growth inhibition. J Natl Cancer Inst 94: 1641-1647, 2002.

14. Kubota T, Hisatake J, Hisatake Y, Said JW, Chen SS, Holden S, Taguchi H and Koeffler HP: PC-Spes: a unique inhibitor of proliferation of prostate cancer cells in vitro and in vivo. The Prostate 42: 163-171, 2000. 
15. Ikezoe T, Chen SS, Heber D, Taguchi H and Koeffler HP: Baicalin is a major component of PC-Spes which inhibits the proliferation of human cancer cells via apoptosis and cell cycle arrest. Prostate 49: 285-292, 2001.

16. Franek KJ, Zhou Z, Zhang WD and Chen WY: In vitro studies of baicalin alone or in combination with Salvia miltiorrhiza extract as a potential anti-cancer agent. Int J Oncol 26: 217-224, 2005.

17. Sartippour MR, Seeram NP, Heber D, Hardy M, Norris A, Lu Q, Zhang L, Lu M, Rao JY and Brooks MN: Rabdosia rubescens inhibits breast cancer growth and angiogenesis. Int J Oncol 26: 121-127, 2005

18. Meade-Tollin LC, Wijeratne EM, Cooper D, Guild M, Jon E, Fristz A, Zhou GX, Whitesell L, Liang JY and Gunatilaka AAL: Ponicidin and oridonin are responsible for the antiangiogenic activity of Rabdosia rubescens, a constituent of the herbal supplement PC Spes. J Nat Prod 67: 2-4, 2004.
19. Lian Z, Fujimoto J, Yokoyama Y, Niwa K and Tamaya T: Herbal complex suppresses telomerase activity in chemoendocrine resistant cancer cell line. Eur J Gynaecol Oncol 22: 347-349, 2001

20. Bonham MJ, Arnold H, Montgomery B and Nelson PS: Molecular effects of the herbal compound PC-Spes: Identification of activity pathways in prostate carcinoma. Cancer Res 62: 3920-3924, 2002

21. Pandha HS and Kirby RS: PC-Spes: Phytotherapy for prostate cancer. Lancet 359: 2213-2214, 2002.

22. Moyer P: Reformulated PC-SPES may become available. Oncol Times 25: 32-35, 2003

23. Shabbir M, Love J and Montgomery B: Phase I trial of PCSpes2 in advanced homone refractory prostate cancer. Oncol Rep 19: 831-835, 2008. 